\title{
Exploring the Development of Humble Leaders in the Context of Agriculture
}

\author{
A. Council ${ }^{1}$, M. Sowcik ${ }^{2}$
}

\section{Abstract}

The complexity of the world today requires leadership that is interconnected rather than selfserving. This is particularly important within the context of agriculture, a field at the forefront of the complex problems associated with the impact of climate change. In recent years, the role virtues play in effective leadership has gained a significant amount of attention. One particular virtue that has seen increased attention in the leadership research is humility. Humility has been identified as a way to counteract the negative outcomes of self-serving leadership, namely, unethical practices and leader narcissism. Over the past several decades, researchers and scholars have begun to shed light on the many benefits this elusive virtue brings to leadership, however, many questions remain, notably, "How do humble leaders develop their leadership?" The present qualitative study found that humble agriculture leaders develop their leadership style through (a) the development of strong personal values, (b) investments in human and social capital, and (c) supportive feedback. The findings from this research provide recommendations for agricultural leadership educators to consider when building leadership programs that have the goal of developing humble leaders ready to address complex problems in the context of agriculture and natural resources.

\section{Keywords}

Leadership development, agricultural leadership, humility development

1. Austin Council, Instructor, Virginia Tech, 175 West Campus Dr., MC 0343 Blacksburg, VA 24061, adc@vt.edu, https://orcid.org/0000-0003-1160-6991

2. Matthew Sowcik, Assistant Professor, University of Florida, 217 Rolfs Hall, Gainesville, FL 32611, sowcik@ufl.edu, https://orcid.org/0000-0002-5630-2281 


\section{Introduction and Problem Statement}

We live in a volatile, uncertain, complex, ambiguous (VUCA) world, burdened with complex, adaptive, problems that hold no easy solutions (Kinsinger \& Walch, 2012; Satterwhite et al., 2015; Heifetz \& Linsky, 2002). This is especially true for those taking on leadership roles in the context of agriculture and natural resources. Whether it is currently addressing the issues of a global pandemic or feeding a population of 9.6 billion people by the year 2050, these are some of the most pressing adaptive challenges our world faces (Stedman \& Andenoro, 2015; Roberts et al., 2016). Due to these present and future complex challenges, effective leadership is critically important. However, leader centric models are still prevalent in the leadership landscape, which may be one reason for increased leader narcissism, unethical behaviors and ineffective leadership practices addressing these complex challenges (Morris et al., 2005). As a result, the role of virtues as an important element of effective leadership has gained traction over the past two decades in the leadership research (Pearce et al., 2006).

With calls for more comprehensive and interconnected virtue driven leadership models (Prime \& Salib, 2014), humility has been brought to the forefront of leadership discourse as a way to counteract leader narcissism and promote more other-centered adaptive leadership practices (Owens \& Hekman, 2012; Peterson \& Seligman, 2004; Morris et al., 2005). As the oftenrepeated quotation attributed to St. Augustine goes, "Humility is the foundation of all the other virtues hence, in the soul in which this virtue does not exist there cannot be any other virtue except in mere appearance" (quoted in Lavelock, et al., 2017). Yet even though humility in agricultural leadership is so critical to address complex problems, little is known about how humble agricultural leaders develop their leadership practices. The current study explores this gap found in the leadership literature associated with the development of humble leaders in the context of agriculture and natural resources.

\section{Theoretical and Conceptual Framework}

Historically, the virtue of humility has been viewed in a negative light (Tangney, 2000). Often, those addressing the virtue describe a humble person as frail and subservient, lacking selfconfidence, and self-admiration (Peterson \& Seligman, 2004). Due to these negative perceptions of humility, it has largely been absent from the early literature on leadership. However, over the past two decades the research on this trait has emphasized its importance on numerous prosocial behaviors and positioned humility as an accuracy of the self (Tangney, 2000), an increased focus towards others (Van Tongeren \& Myers, 2017), and an increase in one's connection to the larger environment (Bollinger \& Hill, 2012). This notion of accuracy influenced Sowcik et al. (2017) definition of humility, which was used in the current study, as "a proper perspective of oneself, one's relationship with others, and one's place within the larger environment" (p. 170).

The connection between the virtue of humility and leadership effectiveness can also be seen in the leadership literature over the past twenty years. Collins (2001), in the book Good to Great: 
Why Some Companies Make the Leap and Others Don't, identified leaders in the most enduring and successful companies and found that each of these leaders demonstrated a blend of personal resolve and humility. Collins was not the only researcher to identify benefits between humility and leadership in the context of organizations. Johnson et al. (2011) discovered humility was a significant predictor of job performance. Vera and Rodriguez-Lopez (2004) discussed the connections between humility and a leader's ability to differentiate between traits like confidence, self-image, and self-appraisal from brashness, narcissism, and inflexibility. Additionally, humility appears to have a positive effect on teams (Rego et al., 2017; Chiu et al., 2016) and prosocial characteristics such as a better ability to receive from others (Exline, 2012), fostering helpfulness (LaBouff et al., 2012), and forgiveness (Powers et al., 2007), all of which are important in effective leadership. While there has been evolving influx of research on the relationship between humility and leadership, there is still scarce research on the development of humble leaders.

Although limited research exists concerning the development of the virtue of humility, there are some guiding beliefs that help to inform the overall development of virtues. According to Li (2016), virtues can be learned, developed, and cultivated. Li's (2016) argument for the cultivation of humility was contingent upon what cultural values (Eastern vs. Western) were in place to foster growth. Others writing on the topic of virtue have argued that humility can develop from a secure relationship with others, which in turn influences secure attachment and lays the foundation for the virtue's development (Dwiwardani et al., 2014; Peterson \& Seligman, 2004; Bowlby, 1973). Finally, "awe-inspiring experiences" have also been linked to the development of humility (Stellar et al., 2018). Stellar et al. (2018) hypothesized that individuals who confront an experience that challenges their worldview, first experience awe, then foster a feeling of self-diminishment, and finally develop a sense of humility. While each of these perspective offer insight into the development of humility, more research is needed to identify the key components associated with the development of humility in effective leaders.

\section{Purpose}

The purpose of the present study was to explore themes that address the development of humble leaders in the context of agriculture and natural resources. Specifically, we sought to answer the question: "How do identified humble leaders in the agriculture and natural resources industry perceive their humble leadership development?"

\section{Methods}

We utilized a basic qualitative design due to the exploratory nature of real-life leadership development experiences among identified humble leaders in the context of the agriculture and natural resources industry. For this study, we sought to understand how identified humble agricultural leaders made sense of their lives and experiences in relationship to their humble leadership development. The research sample consisted of five $(n=5)$ leaders in the agriculture and natural resources industry. Participants for the study were identified by a key informant, 
who was the director of a cohort-based agricultural leadership program housed in a large landgrant university in the Southeastern United States. This agricultural leadership development program "...develops and refines the leadership capabilities of leaders in agriculture and natural resources" ("Program Overview," 2020). According to Marshall (1996), "A key informant is an expert source of information" (p. 92) because the informant has achieved status in their community and holds a "position of responsibility and influence" (Marshall, 1996, p. 92).

In collaboration with the key informant, we established the following criteria to select the study's participants: (a) the individual must have held a high level leadership position in the agriculture and natural resources industry, (b) the individual must have had a positive reputation within his/her organization and throughout the industry, and (c) the individual was seen as someone who practices humility, based on the definition of humility used in this study. Based on the established criteria for the study, we were given a list of 20 potential participants by the key informant, which was comprised of six women and fourteen men. After reaching out to all candidates, five individuals were interviewed based on their availability within the timeframe of the study. The participants selected based on their availability included five men, three who identified as being of Hispanic, Latino, or Spanish origin, and two who identified as white.

The researchers traveled to each participant's physical location, which included a combination of work sites, offices, and places of business. Each interview lasted between 45 and 90 minutes. The participants, during the time of the study, were all in a senior leadership position and represented a different context in the agriculture and natural resources industry. For example, participant one, Gilbert (48 years old, white male, of Hispanic, Latino, or Spanish origin) worked as the Executive Director in an agriculture insurance and advocacy company. The second participant, John (46 years old, white male), was a Senior Manager in the landscaping and nursery industry. Roy (47 years old, white male), participant three, is a Vice President in the forestry industry. Participant four, David (52 years old, white male, of Hispanic, Latino, or Spanish origin), owned and led an agrochemical company. Lastly, Cole (41 years old, white male, of Hispanic, Latino, or Spanish origin), participant five, worked as a Senior Manager in the agricultural finance and lending industry.

Semi-structured interview questions addressed the participants' development into a humble leader. For example, one of the first questions asked was, "What kinds of life experiences have impacted your development as a leader?" Another critical question was, "What kinds of relationships with others have contributed to your leadership development?" During each interview, the primary investigator took extensive, hand-written field notes, which were compiled into a secure digital database. All interviews were digitally recorded and transcribed using an external organization, NoNotes.com. Member checking of both the transcripts and emergent categories occurred to determine accuracy and increase the reliability of the study. The data analysis process was inductive, using the constant comparative method and was completed by hand by the primary researcher. First, the process of in-vivo coding was used based on the language used by the participants to develop initial categories (Creswell, 2013). This was repeated several times until the data became saturated, and no new codes emerged 
(Fusch \& Ness, 2017). Once the codes emerged, inter-coder reliability was established by having another researcher familiar with humility, leadership development, and qualitative methods, serve as a "rigorous examiner and auditor" who concurred with all categorization of the data (Saldaña, 2015, p. 37). Lastly, it is important to recognize the relationship we had with the study, being stakeholders in the context of agriculture and educators developing the next generation of leaders at a large land grant higher education institution in the southeast United States.

\section{Findings}

The central inquiry explored in this paper was the development process of identified humble leaders in the context of agriculture and natural resources. As such, data that emerged from this inquiry captured the different developmental experiences throughout the course of the humble leaders' lives. This question aligns with the notion of leader development as suggested by Avolio and Hannah (2008), "the factors that contribute to making a leader are in part a subset of all the formative experiences an individual has accumulated throughout the individual's life course that may position the individual to more effectively assume leadership roles." (p. 333-334). Three key themes emerged from the humble leaders' perception of their leadership development. The first theme found in the coding of the interviews was the leader's anchoring personal values, which strongly promoted their humble leadership. Three subthemes also surfaced out of the first major theme that addressed how the leader's anchoring personal values were established including (a) value development influenced by family, (b) value development influenced by personal relationships with significant people, and (c) value development from significant life changes and experiential learning. Additionally, two more main themes were identified when exploring humble leader's development including investment in human/social capital and the supportive feedback received by the leaders.

\section{Developed Anchoring Personal Values}

The first theme that emerged from the identified humble leaders' overall perceptions of their development came from the anchoring personal values they gained throughout their lives. The humble leaders' identified three different sources from which these values were established in their lives including: (a) values influenced by family, (b) values from personal relationships with significant people, and (c) values from significant life changes and experiential learning.

\section{Family Values}

A majority of the humble leaders expressed values learned from relationships with their parents, siblings, and/or other close relatives. For example, Gilbert described that his father taught him values such as being honest and truthful: "With my dad, always be honest. It's easy to be honest and truthful than to try to backtrack or cover up your lies..." Similarly, David mentioned how he learned fairness from his dad: "One of the things my dad impressed upon me was fairness." These perspectives provide insight into the role family played on humble leaders' perceptions of their personal values. 


\section{Values from Significant People}

A second source of value development, from the perspective of the humble leaders, surfaced from the personal relationships they had with significant people in their lives. In each case, the significant person in the humble leader's life directly taught them values or modeled a particular value, which was observed by the humble leader. Many of the humble leaders discussed specific relationships they had over their life with identified mentors, friends and/or peers, teachers, and role models. For example, John learned the value of gratitude from a mentor: "He [Mr. H] also taught me thank you notes and the importance of sending a simple note to someone." Additionally, Cole observed his teachers and their kindness, as well as their ability to go "above and beyond" in their roles. For example, his second-grade teacher would "always take family trips and always send postcards" and he remembered how that made him feel. Furthermore, this humble leader felt like his teachers "went above and beyond" and this was not something that all teachers would have done. He described them as "instrumental" in his development.

\section{Values from Significant Life Changes and Experiential Learning}

All five of the humble leaders described life experiences and/or significant life changes that influenced their value development. One of the humble leaders developed gratitude through his experiences traveling to India, where he saw the effects of poverty and the class system. Gilbert said, "The end of the story is, when you get back, you appreciate so much more what you have here. It's nice to see what you see on National Geographic or Discovery channel but it's not the same when you're walking there and you're smelling it." All of the accounts saw the humble leaders go through a change and/or learning experience, which facilitated development of specific values.

\section{Investment in Human and Social Capital}

The second theme that emerged from the perspective of the identified humble leaders addressing their leadership development was an investment each made in their human and social capital. Four out of the five leaders described going through a formal agricultural leadership development program as an important developmental opportunity where they became more accurately aware of themselves, their relationship with others, and how they fit into a larger agricultural context. For example, during his time in this agricultural leadership development program, one of the humble leaders, Roy, suggested that the program showed him the key components of humility, accuracy of self, others, and the larger environment. He suggested,

What [the leadership program] did for me as a leader is it, first of all, taught me about myself. It helped me understand my personality, how I process information, and what makes me the way I am. Then what it did was it taught me about my local community, others, and what my local community dynamics are. We then explored the national scene and where we are as a country, for example policy on the national level. Then the last thing that the program does is it helps us look internationally. What does agriculture look like on the international landscape. 
John's experiences with a leadership program also helped him develop as a leader through focusing on himself, others, and the bigger picture. For example, John developed relationships that influenced his leadership in terms of personal openness and team building:

I always felt I was fairly open but again [the program] shined a light on that...I think [the program] reminds you of certain things and so, being open to others, team building, and what side of the table or where your bread plate is.

Additionally, John experienced the power of participating in something bigger than himself, stating:

...but above all I guess is a sense of doing something more than just for you. I have told several people considering going into the program that, yes, it's a two-year program but is a lifelong commitment. Again, I wouldn't have had that if not for the [program].

Finally, the importance of humility development through the participation in a leadership program was simply and concisely stated by Gilbert who said, "I think [the program] has helped me learn more about myself and about everything that's happening around us." This insight into the intrapersonal, interpersonal, and the larger environment laid a foundation for the humble leaders' development.

\section{Supportive Feedback}

In all five cases, the humble leaders discussed the third emergent theme in the study, how they were influenced by supportive feedback given in their personal and professional lives. Humble leaders were shown encouraging feedback from a variety of support sources including friends, peers, identified mentors, or teachers. For example, Roy mentioned friends in his life who continue to be a source of supportive feedback to him by revealing blind spots in his leadership and encouraging him to think differently. Roy knows how "there's blind spots in every man's life" and what he tries to do is surround himself with "one or two good men" that care about him and love him, who he allows to "speak truth" to him and promises to them that he will listen to it, even if it's "uncomfortable." Furthermore, Roy explained what the process of feedback looks like through his friends:

What happens when we put those blinders on is we get in a comfort zone and we don't want to break out of it. We want people to react the way we want them to react. We want them to respond the way we want them to respond. But because you have blinders on you can't see. You can't see the character flaws that you've got. Those guys can actually help me see that.

Roy's friends helped him see the blind spots in his leadership and continue to provide a level of humility in the way he observes himself, others, and his environment.

Another humble leader, David suggest that his friends and peers have been a source of support and feedback for his development by instilling confidence in him and affirming his leadership. For example, during his time in college David and his friends were putting together a "slate of officers" to run for student body positions and David's friends told him they wanted him "to be at the top", which was "a real compliment" to David and "instilled a different kind of confidence" in him. This newly instilled confidence allowed David to more accurately see himself and the leadership role he could play within the institution. Later in life, when he was 
considering running for a position within the Certified Crop Advisors (CCA) organization, David remembered his peers looking "around the room" and said "you are the guy that can lead us forward.' From his perspective, David described this experience as "humbling" because it was a "challenge to rise to the occasion" and to not let others down.

Anytime you are recognized, I think it's always humbling because you get to reflect on the question, 'Do I really deserve this?' When you get awards, when you get recognition, when you get any win for an election.

Finally, John described a mentor he had in college who believed in him, trusted him, and recognized his ability to be an advocate for the agriculture industry saying, "...to have Dr. C have belief or trust that I can advocate for the University of Florida to me was a big thing. Dr. C was always someone I always looked up to..." David also described a particular experience where confidence was instilled in him from his peers in high school suggesting,

...in high school I was treasurer of our sleight of officers, in college I was the president and that was a really good experience when we were trying to put a slate together for my class and my peers, my friends said, 'We want you to be at the top.' Me? Why? 'We think you're the guy.' That was a real compliment and instilled confidence.

These recollections shed light into the role supportive feedback played in the humble leaders' pathways to leadership development.

\section{Conclusions, Discussion, and Recommendations}

The agriculture and natural resources industry is in need of leaders who can address complex problems at the local, state, national and global levels. The findings of this study begin to shed light on how humble agricultural and natural resource leaders view their leadership development. The first of these factors includes the development of an individual's personal values and the role they play in developing humble leaders. Tangney (2002) wrote that

"...parents, teachers, teachers, heroes and community leaders all play a role in modeling (or not modeling) a sense of humility for the subsequent generation" (p. 417). Life experiences also emerged as a theme that influenced the development of personal values that contributed to a humble leader's development. All five identified humble leaders mentioned a pertinent life experience or change that contributed to their personal and professional values. In each case, researchers point to these experiences as opportunities for individuals to go through a deep reflection or altered sense of identity, all of which have been argued to facilitate the cultivation of humility.

Based on these findings, leadership development programs should help participants identify which specific values guide their behavior, how to express those values in their relationships with others, and how these values connect to the larger community. In addition to intentionally drawing out individual values that leaders already prioritize, leadership programs can provide experiences shaping the values of their participants. Agricultural and natural resource leadership development programs that provide participants with these critical experiences, 
such as community engagement opportunities or international leadership experiences, may have a greater likelihood of developing humble leaders.

The second factor critical for developing humble agricultural and natural resource leaders, based on the study's findings, was the influence placed on human and social capital. A majority of the humble leaders discussed the critical role a particular leadership program played in their development. These findings highlight the critical importance leadership programs have when it comes to providing time for individuals to understand one's self (human capital) and how one relates to others and the larger environment (social capital). This is in line with the research on humility, which asserts that humility is "an accurate assessment of one's abilities and achievements" (Tangney, 2002, p. 413) and "is also about an orientation toward others" (Van Tongeren \& Myers, 2017, p. 155). In this way, the leadership program provided the time and resources for these leaders to focus on themselves, others, and the larger environment, allowing for increased accuracy of their perspective within these areas.

Agriculture and natural resource leadership development programs should look to emphasize both teaching for personal leadership development, as much as it emphasizes educating participants about different leadership theories and practices. This time spent developing one's intrapersonal and interpersonal knowledge/skills can be a useful starting point to develop humble leadership. Additionally, time to reflect on content and experiences that allow participants to explore themselves, others and the larger environment is critical to humility development. The time and resources allotted to these experiences are unlikely to happen outside of the leadership development program but are crucial in the development of humble leaders.

A third factor found in the research was the role of supportive feedback in developing humble leaders. The type of supporting relationships described by the humble leaders provided a secure attachment, which research has shown virtues such as humility develop (Dwiwardani et al., 2014). Out of these secure attachments both positive and constructive feedback was presented to the humble leader allowing them to have a more accurate picture of their competencies, relationships with others, and perspective in a particular context. The findings from this study suggest that agricultural leadership development programs should promote supportive feedback opportunities for their participants as a way to cultivate humility in participants. One example, mentoring, can set up a structure that would give participants in the leadership program a chance to learn more about themselves by receiving continuous feedback from a more experienced individual.

\section{Recommendations for Future Research}

In effort to increase the validity and reliability of the current study, with more time and resources, a researcher should utilize a Delphi Method to select the humble leaders. Additionally, increasing the diversity of participants related to gender, demographics, and location would provide additional insights into humble leader development. Future research should also explore the relationship between personal values and humility. While this research does identify the important role personal values play in the development of humble leaders, 
future research should explore whether humble leaders are more inclined to possess particular personal values. If particular values do emerge, it would be important to explore how the introduction of these values takes place in an agricultural leadership program.

Additionally, future research should explore what types of leadership development programs provide opportunities for increased focus on human and social capital. While this study does identify leadership programs as important in the development of humble leaders, there are numerous types of agricultural and natural resources leadership program models. Further exploration is need into the impact different programs' length, content, focus, and delivery have on humble leader development.

\section{References}

Andenoro, A. C., Allen, S. J., Haber-Curran, P., Jenkins, D. M., Sowcik, M., Dugan, J. P., \& Osteen, L. (2013). National leadership education research agenda 2013-2018: Providing strategic direction for the field of leadership education. Association of Leadership Educators. http://leadershipeducators.org/ResearchAgenda.

Avolio, B. J., \& Hannah, S. T. (2008). Developmental readiness: Accelerating leader development. Consulting Psychology Journal: Practice and Research, 60(4), 331-347. https://doi.org/10.1037/1065-9293.60.4.331

Bennis, W. G., \& Thomas, R. J. (2002, September). Crucibles of leadership. Harvard Business Review, 60-69. https://hbr.org/2002/09/crucibles-of-leadership

Bollinger, R. A., \& Hill, P. C. (2012). Humility. In T. G. Plante (Ed.), Religion, spirituality, and positive psychology: Understanding the psychological fruits of faith (pp. 31-47). Praeger.

Bowlby, J. (1973). Separation: Anxiety and anger. Basic Books.

Chiu, C.-Y. (C.), Owens, B. P., \& Tesluk, P. E. (2016). Initiating and utilizing shared leadership in teams: The role of leader humility, team proactive personality, and team performance capability. Journal of Applied Psychology, 101(12), 1705-1720. https://doi.org/10.1037/apl0000159

Creswell, J. W. (2013). Qualitative inquiry and research design. Sage.

Collins, J. C. (2001). Good to great: Why some companies make the leap and others don't. Harper Collins.

Day, D. V. (2000). Leadership development: A review in context. The Leadership Quarterly, 11(4), 581-613. https://doi.org/10.1016/S1048-9843(00)00061-8 
Dwiwardani, C., Hill, P. C., Bollinger, R. A., Marks, L. E., Steele, J. A., Doolin, H. N., \& Davis, D. E. (2014). Virtues develop from a secure base: Attachment and resilience as predictors of humility, gratitude, and forgiveness. Journal of Psychology \& Theology, 42(1), 83-90. https://doi.org/10.1177/009164711404200109

Exline, J. J. (2012). Humility and the ability to receive from others. Journal of Psychology and Christianity, 31(1), 40-51.

Fusch, P. I., \& Ness, L. R. (2015). Are we there yet? Data saturation in qualitative research. The Qualitative Report, 20(9), 1408-1416. http://www.nova.edu/ssss/QR/QR20/9/fusch1.pdf

Gardner, J. (1993). On leadership. Simon and Schuster.

Heifetz, R., \& Linsky, M. (2002). Leadership on the line: Staying alive through the dangers of leading. Harvard Business Review Press.

Johnson, M. K., Rowatt, W. C., \& Petrini, L. (2011). A new trait on the market: Honesty-humility as a unique predictor of job performance ratings. Personality and Individual Differences, 50(6), 857-862. https://doi.org/10.1016/j.paid.2011.01.011

Kinsinger, P., \& Walch, K. (2012). Living and leading in a VUCA world. Thunderbird, 1-4.

Kuczmarski, S. S., \& Kuczmarski, T. D. (1995). Values-based leadership. Prentice Hall.

LaBouff, J. P., Rowatt, W. C., Johnson, M. K., Tsang, J. A., \& Willerton, G. M. (2012). Humble persons are more helpful than less humble persons: Evidence from three studies. The Journal of Positive Psychology, 7(1), 16-29. https://doi.org/10.1080/17439760.2011.626787

Lavelock, C. R., Worthington, E. L., Griffin, B. J., Garthe, R. C., Elnasseh, A., Davis, D. E., \& Hook, J. N. (2017). Still waters run deep: Humility as a master virtue. Journal of Psychology and Theology, 45(4), 286-303. https://doi.org/10.1177/009164711704500404

Li, J. (2016). Humility in learning: A confucian perspective. Journal of Moral Education, 45(2), 147-165. https://doi.org/10.1080/03057240.2016.1168736

Marshall, M. N. (1996). The key informant technique. Family Practice, 13(1), 92-97. https://doi.org/10.1093/fampra/13.1.92

Morris, J. A., Brotheridge, C. M., \& Urbanski, J. C. (2005). Bringing humility to leadership: Antecedents and consequences of leader humility. Human Relations, 58(10), 1323-1350. https://doi.org/10.1177/0018726705059929 
Owens, B. P., \& Hekman, D. R. (2012). Modeling how to grow: An inductive examination of humble leader behaviors, contingencies, and outcomes. Academy of Management Journal, 55(4), 787-818. https://doi.org/10.5465/amj.2010.0441

Pearce, P., Waldman, D., \& Csikszentmihalyi, M. (2006). Virtuous leadership: A theoretical model and research agenda. Journal of Management, Spirituality \& Religion, 3(1), 6077. https://doi.org/10.1080/14766080609518611

Peterson, C., \& Seligman, M. E. (2004). Character strengths and virtues: A handbook and classification. Oxford University Press.

Piff, P. K., Dietze, P., Feinberg, M., Stancato, D. M., \& Keltner, D. (2015). Awe, the small self, and prosocial behavior. Journal of Personality and Social Psychology, 108(6), 883-899. https://doi.org/10.1037/pspi0000018

Powers, C., Nam, R.K., Rowatt, W.C \& Hill, P.C. (2007). Associations between humility, spiritual transcendence, and forgiveness. In R.L Piedmont (Ed.), Research in the social scientific study of religion, Volume 18 (pp. 75-94). Brill.

Prime, J., \& Salib, E.R. (2014). Inclusive leadership: The view from six countries. Catalyst, 120122. https://www.catalyst.org/research/inclusive-leadership-the-view-from-sixcountries/

Rego, A., Owens, B., Leal, S., Melo, A. I., Cunha, M. P., Gonçalves, L., \& Ribeiro, P. (2017). How leader humility helps teams to be humbler, psychologically stronger, and more effective: A moderated mediation model. The Leadership Quarterly, 28(5), 639-658. https://doi.org/10.1016/i.leaqua.2017.02.002

Roberts, T. G., Harder, A., \& Brashears, M. T. (2016). American Association for Agricultural Education national research agenda: 2016-2020. http://aaaeonline.org/resources/Documents/AAAE National_Research_Agenda_20162020.pdf

Russell, R. F. (2001). The role of values in servant leadership. Leadership \& Organization Development Journal, 22(2), 76-84. https://doi.org/10.1108/01437730110382631

Saldaña, J. (2015). The coding manual for qualitative researchers. Sage.

Satterwhite, R., Miller, W. M., \& Sheridan, K. (2015). Leadership for sustainability and peace: Responding to the wicked challenges of the future. In M. Sowcik, T. Andenoro, M. McNutt \& S. Murphy (Eds.), Leadership 2050: Critical challenges, key contexts, and emerging trends, (pp. 59-74). Emerald Group. 
Schwartz, S. H., \& Bilsky, W. (1990). Toward a theory of the universal content and structure of values: Extensions and cross-cultural replications. Journal of Personality and Social Psychology, 58(5), 878-891. https://doi.org/10.1037/0022-3514.58.5.878

Sowcik, M. J., Andenoro, A. C., \& Council, A. (2017). Addressing the biggest (baddest) and best ideas ever: Through the lens of humility. Journal of Leadership Education, 16(4), 164179. https://doi.org/10.12806/V16/14/T5

Stedman, N. L., \& Andenoro, A. C. (2015). Emotionally engaged leadership: Shifting paradigms and creating adaptive solutions for 2050. In M. Sowcik, T. Andenoro, M. McNutt \& S. Murphy (Eds.), Leadership 2050: critical challenges, key contexts, and emerging trends, (pp.145-156). Emerald Group.

Stellar, J. E., Gordon, A., Anderson, C. L., Piff, P. K., McNeil, G. D., \& Keltner, D. (2018). Awe and humility. Journal of Personality and Social Psychology, 114(2), 258-269. https://doi.org/10.1037/pspi0000109

Tangney, J. P. (2002). Humility. In C. R. Snyder \& S. J. Lopez (Eds.) Handbook of positive psychology (pp. 411-719). Oxford University Press.

Tangney, J. P. (2000). Humility: Theoretical perspectives, empirical findings and directions for future research. Journal of Social and Clinical Psychology, 19(1), 70-82. https://doi.org/10.1521/jscp.2000.19.1.70

Van Tongeren, D. R., \& Myers, D. G. (2017). A social psychological perspective on humility. In E. L. Worthington, Jr., D. E. Davis, \& J. N. Hook (Eds.), Handbook of humility (pp. 150-164). Routledge.

Vera, D., \& Rodriguez-Lopez, A. (2004). Strategic virtues: Humility as a source of competitive advantage. Organizational Dynamics, 33(4), 393-408. https://doi.org/10.1016/j.orgdyn.2004.09.006

(C) 2020 by authors. This article is an open access article distributed under the terms and conditions of the Creative Commons Attribution license (http://creativecommons.org/licenses/by/4.0/). 